ВПЛИВ СІМ'Ï НА РОЗВИТОК ОСОБИСТОСТІ В.І. ВЕРНАДСЬКОГО

\title{
THE INFLUENCE OF THE FAMILY ON THE DEVELOPMENT OF V.I. VERNADSKY'S PERSONALITY
}

УДК 159.954 - 043.86:[929:001] DOI https://doi.org/10.32843/26635208.2020.14.15

\footnotetext{
Виноградова В.є.

к.пед.н., доцент,

завідувач кафедри психології та педагогіки

Таврійський національний університет імені В.І. Вернадського
}

\begin{abstract}
Стаття присвячена родинним фракторам, які вплинули на формування особистості B.I. Вернадського. Мета cmammi полягає у дослідженні основних чинників сімейного середовища, які вплинули на В.І. Вернадського в процесі розвитку його особистості. Проаналізовано вплив батьків, родичів, близького оточення сім'ї Вернадських. Досліджено вплив природи та мікросередовища на вибір майбутнього професійного шляху видатного науковця. Розглядаються методи виховання, сімейні иінності, традииії родини. Аналізується життя В.І. Вернадського у роки дитинства та юнацтва. Досліджується харківський період зростання B.I. Вернадського. Розглядаються питання формування особистості видатного науковия в умовах звичайного життя. У роботі приділена увага цінностям родини, які вплинули на формування особистості B.I. Вернадського. Серед них були визначені такі: внутрішня свобода, самоповага, воля, мудрість, розум, урівноваженість в особистих і громадських справах, оптимізм, почуття гумору, терпеливість, зовнішньоетична вихованість, самостійність та критичність мислення, твердість слова, точність, самокритичність, почуття відповідальності, активне слухання, шляхетність і відповідальність у стосунках з особою іншої статі, самореалізація, розвиток естетичних смаків і творчих естетичних здібностей.

у статті визначені основні фрактори, що вплинули на розвиток особистості B.I. Вернадського. До них були віднесені такі: дворянське походження; особистісно-природничий чинник; позитивний вплив мікросередовища, спілкування у колі високоінтелектуальних людей.

Тобто світогляд В. Вернадського у родині формувався під впливом батька, старшого брата Миколи, а також найближчого оточення наукової еліти. Отже, доброзичлива домашня атмосфрера у родині Вернадських, яка була пронизана духовністю, прихильністю один до одного членів сім'ї, взаєморозумінням, бажанням бути корисним для своїх рідних, спільна праця, родинні свята, народні звичаї та обряди надзвичайно глибоко вплинули на становлення та розвиток особистості В.І. Вернадського.

Ключові слова: В.І. Вернадський, особистість, розвиваюче середовище, сім'я, творчість, цінності.
\end{abstract}

The article deals with family factors that influenced the formation of V.I. Vernadsky's personality. The purpose of the article is to study the main factors of the family environment that influenced V.I. Vernadsky in the process of development of his personality. The influence of parents, relatives and the close circle of the Vernadsky family has been analyzed. The influence of the nature and microenvironment on the choice of the future professional path by the outstanding scientist has been studied. The methods of education, family values, family traditions have been considered. V. Vernadsky's life in the years of childhood and youth has been analyzed. The Kharkiv period of Vernadsky's growth has been researched. The issues of forming the personality of an outstanding scientist in his ordinary life have been considered. The work focuses on the values of the family which influenced the formation of Vernadsky's personality. Among them the following were identified: inner freedom, self-esteem, will, wisdom, intelligence, balance in personal and public affairs, optimism, sense of humor, patience, external ethical upbringing, independence and critical thinking, firmness of the word, accuracy, self-criticism, sense of responsibility, active listening, nobility and responsibility in relations with a person of the opposite sex, self-realization, the development of aesthetic tastes and creative aesthetic abilities.

The article deals with the main factors that influenced the development of V.I. Vernadsky's personality. The following were attributed to them: a noble origin; personality-natural factor; the positive influence of the microenvironment, communication in the circle of highly intelligent people. That is Vernadsky's worldview in the family was formed under the influence of his father, his elder brother Mykolay, as well as of the closest circle of the scientific elite. Therefore, the friendly homely atmosphere in the Vernadsky's family which was permeated with spirituality, affection of family members, mutual understanding and desire to be useful for their relatives, joint work, family holidays, folk customs and rituals had an extremely profound influence on the formation and development of V.I. Vernadsky's personality.

Key words: V.I. Vernadsky, personality, developmental environment, family, creativity, values.
Постановка проблеми. Загальновідомо, що основи формування особистості закладає сім'я. Родина з її історичними традиціями та моральним багатством впливає як на духовний світ дітей, який ґрунтується на рідній мові, культурі, традиціях, спирається на народну, світову культуру, загальнолюдські і національні цінності, так і враховує їхні індивідуальні нахили і здібності. Сім'я є мікросоціумом, в якому роз- вивається особистість дитини. Безсумнівно, що на формування особистості впливає як середовище родини, так й інші системи, які безпосередньо на неї впливають. Слід відзначити, що саме сім'я здебільшого впливає на формування цінностей, поглядів та інтересів особистості, створює умови для розвитку їі природних задатків. Необхідно виявити фактори, які не лише діють на формування особи- 
стості в родинному колі, а й розвивають здібності видатних особистостей, формують їхній світогляд та наукове мислення.

Формування особистості потребує довготривалого, системного впливу. Можливості нормального функціонування сім'ї як соціального інституту визначаються низкою факторів, серед яких досить важливим $є$ її культурно-освітній, ціннісний, психологічний, матеріальний та інші рівні.

Отже, необхідно дослідити умови, які вплинули на формування особистості майбутнього науковця. Тому слушно дослідити вплив соціальних, психологічних та економічних факторів родини Вернадських на формування особистості В.І. Вернадського.

Аналіз останніх досліджень і публікацій. Сучасні науковці досліджують психолого-педагогічні, соціальні, економічні, демографічні, соціологічні та інші аспекти родини. Нині доволі активно публікуються роботи впливу виховання на формування особистості дитини. В Україні чинникам розвитку особистості в сім'ї приділяється окрема увага.

У дослідженнях науковці Р. Вайнола, А. Капська, О. Матвієнко, В. Москалець, І. Сопівник розглядають сім'ю як соціальний інститут виховання. О. Вишневський досліджує природу та систему цінностей виховання дитини. О. Демчук, Л. Корецька, З. Охрименко, В. Прит, C. Тесленко розглядають сімейні цінності в ракурсі їх впливу на інститут життєдіяльності. О. Пенькова досліджує родину як чинник розвитку духовності юнаків.

Щодо дослідження впливу родини на формування особистості В.І. Вернадського, то цій проблемі присвячені роботи істориків Т. Бевз, Л. Гумілевського, К. Ситника, В. Шмиговської та ін. Однак необхідно відзначити, що нерозглянутим залишається питання психологічних аспектів розвитку особистості В.І. Вернадського, а також формування Володимира Івановича як творчої особистості. Необхідно дослідити передумови розвитку його наукового таланту, життєві події, які вплинули на розкриття творчого потенціалу і які нерозривно пов'язані з основними етапами життя видатного діяча науки. Тому цікавим видається погляд на період зростання майбутнього науковця у родинному колі.

Формулювання цілей статті. Мета статті дослідити вплив родини Вернадських на розвиток особистості майбутнього науковця. Завдання дослідження полягає: 1) в аналізі наукової літератури з такої проблематики; 2) у висвітленні основних факторів мікросередовища, які вплинули на розвиток особистості В.І. Вернадського.

Виклад основного матеріалу дослідження. Розглянемо на прикладі родини Вернадських шляхи розвитку видатного діяча науки В.І. Вернадського. Володимир Іванович Вернадський народився 12 березня 1863 року в Петербурзі. Його батьки мали дворянське походження та мали гарну освіту. Батько Іван Васильович народився у Києві, закінчив університет Святого Володимира, де згодом став професором політичної економії і статистики, походив з роду дворян. Мати Анна Петрівна Костянтинович закінчила Київський приватний пансіон ім. генерала Левашова й мріяла стати співачкою, походила зі старшинсько-дворянського роду.

У родині Вернадських було четверо дітей: старший брат Микола від першого шлюбу батька, Володимир та дві молодші сестриблизнючки Ольга і Катерина. Перші п'ять років життя Володимира пройшли у Санкт-Петербурзі. Потім у зв'язку із хворобою батька сім'я переїхала до Харкова. Дитинство Володимир Іванович провів в Україні. Про період, коли сім'я Вернадських жила у Харкові, Володимир Іванович пригадував як безтурботний та найщасливіший: «Жили ми добре, заможно, всі наші бажання виконувалися дуже швидко, навіть надто швидко» [1, с. 30].

У 1875 році родина здійснила довгу подорож Європою, досвід цієї мандрівки залишився в його пам'яті на все життя i, безумовно, надихнув його на навчання в цих країнах згодом. У 1876 році родина повернулася до Петербурга.

Стосунки між батьками Володимира Івановича були дуже дружніми. В.І. Вернадський пригадував: «Вони любили одне одного надзвичайно, я не пам'ятаю ніколи, щоб між ними відбувалася сварка, та, здається, її й не було ніколи» [3, с. 22]. Необхідно відзначити, що стосунки подружжя необхідно розглядати крізь призму духовного самовизначення. Имовірно, що любов чоловіка і дружини може стати головним фактором, що виховує дитину. Саме любов батьків один до одного, а не тільки любов до дитини. Отже, у сім'ї Вернадських панувала атмосфера любові, довіри, свободи вибору та розвитку.

На перший погляд Володимир Іванович зростав у звичайній сім'ї. Однак, якщо звернутися до листування науковця зі своєю дружиною, він розкриває особливості характеру своїх батьків та родичів. Необхідно відзначити, що особливу роль у розвитку особистості Володимира Вернадського мав його батько. Він займався професорською діяльністю, спочатку викладав фінансове право, згодом політичну економію. Саме батько Іван Васильович займався вихованням сина.

Володимир Іванович мав багато спогадів про батька, який, безумовно, відіграв головну роль у формуванні особистості сина та його життєвої філософії. В.І. Вернадський згадував: «У нього була дивна манера впливати на мене. 
Він соромив мене, коли я чогось не знав, і говорив, що у мене, у моїй волі $є$ повна можливість знати і я повинен цією можливістю користуватися, а якщо я нею не користувався, то винен я, а не інші. Що інші цього не знають, як і я, анітрохи мене не повинно виправдовувати в моїх очах. А так само не виправдовує і в його очах» [5, с. 31]. На прикладі батька і під його впливом Володимир Вернадський осягав важливість, необхідність систематичної освіти, заглибленості в певну сферу діяльності.

Також Іван Васильович Вернадський сформував у сина інтерес до науки, любов до людей. Володимир Іванович доволі рано навчився читати і багато годин проводив з книжками, при цьому він читав різноманітну літературу: географію, йому подобались книжки про мандрівників, про природу, у п'ять років цікавився історією та прочитав цілу низку книжок. «Найсвітлішими хвилинами уявлялися мені тоді ті книги і думки, які ними викликалися, і розмови з батьком і моїм двоюрідним дядьком Є.М. Короленком» [1, с. 30]. Отже, з раннього дитинства В.І. Вернадському було цікаво знаходити та систематизувати різні факти. Про це також свідчать його спогади у листі Н.Є. Старицькій, де він описує, як у ранньому віці продивлявся та розкладав батькові папери біля письмового стола. Продивляючись журнали, які виписував батько, відзначав картинки, які в них були, та запам'ятовував їх, що свідчить про інтенсивний розвиток когнітивних процесів, таких як пам'ять та уява, які нерозривно пов'язані з креативним мисленням. Тобто батьки прищепили Володимиру інтерес до книг, а це, своєю чергою, стало одним з головних чинників, що вплинуло на розвиток особистості. Взагалі найулюбленішим місцем у будівлі Вернадських для нього був батьківський кабінет. Тобто сім'я Вернадських створювала умови, що випереджали розвиток дитини, а також сприяли ранньому інтелектуальному розвитку Володимира Івановича.

Ще однією з важливих постатей у формуванні Володимира Вернадського як особистості та становленні його як науковця виступив, безперечно, його старший на одинадцять років брат по батькові - Микола Вернадський. Він також багато часу приділяв освіті Володимира: навчив його читати, писати, цікавитися наукою та поринати у книжкові мандри. Однак Микола рано помер і ця подія сильно вразила Володимира. Скоріш за все це навчило його цінувати життя і ставитися бережливо до кожної хвилини власного життя. Пізніше він написав: «Немає нічого більш цінного у світі та нічого, що потребує більшого збереження та поваги, як вільна особистість» [3, с. 237].

У харківський період у Вернадських часто бували професор Харківського університету Дмитро Каченовський та письменниця
Христина Алчевська. Також багато часу Володимир проводив з двоюрідним дядею Є.М. Короленком. На нашу думку, він зробив вагомий внесок у розвиток особистості В.І. Вернадського. Володимир Іванович пригадував, що вони довгими вечорами багато про що спілкувалися.

Євграф Максимович любив гуляти перед сном у супроводі свого юного друга Володимира Вернадського. У ці хвилини ніщо не заважало поважному Євграфу Максимовичу фантазувати вголос. Він не визнавав Бога, і зоряне нічне небо викликало у нього надзвичайні образи. Він не сумнівався в тому, що далекі світи населені розумними істотами. Більш того, він вірив, що всі світи, сузір'я зірок і галактик не розкидані в світовому просторі випадково, не хаотичні, але становлять щось єдине, нескінченно складне, організоване і розумне. Подібні думки глибоко врізалися в душу вразливого хлопчика. Це спілкування сприяло розвитку уяви, формуванню інтересів хлопчика і рано пробудило в ньому здатність до самостійного мислення.

Таким чином дядько заохочував та підтримував у юного В. Вернадського жагу до природничих наук. А також у прогулянках-бесідах 3 Євграфом Максимовичем молодий Володимир отримував уроки наукового мислення. Володимир Іванович пригадував про Короленка: «Ніколи не забуду того впливу, того враження, які мав на мене цей старий у перші роки мого свідомого життя, і мені здається, що не тільки за себе, а й за нього я повинен працювати, що не тільки моє, а і його життя залишиться прожитим дарма, якщо я нічого не зроблю» [1, с. 32]. Справа в тому, що Є. Короленко не встиг закінчити свою роботу до кінця і передав рукопис Володимиру Івановичу. Отже, Вернадський вирішив продовжити його справу.

Значно вплинула на формування особистості Володимира няня Олександра Петрівна. Володимир Вернадський пригадував ії як людину «надзвичайно добру і розумну». Вона сприяла формуванню релігійного світогляду, оскільки «релігійні погляди в дитинстві розвивались головним чином завдяки впливу няні, дітей охоронців банку, з якими грався, і потім під впливом читання священних книг, причому особливо сильно на мене діяли тоді «житія» і «Старий заповіт». У сім'ї Вернадських батько був деїстом, а мати - невіруюча. Володимир Іванович пригадує, що «жодного разу не був на вранішній службі перед Світлим Воскресінням...» $[1$, с. 32]. Також на формування релігійного світогляду вплинули його товариші по гімназії. Двоє братів, з якими він спілкувався, були синами священника.

Такожнянявиховувалашанобливеставлення до людей будь-якої класової приналежності. Вона зауважувала про те, що «тепер немає крі- 
паків і поміщиків - усі люди» [3, с. 35]. Саме ця людина була однією з перших, яка допомагала йому формувати критичне мислення. 3 цього ми бачимо, що, починаючи з дитинства, люди, які оточували його, допомагали розвивати особисту думку на різні речі, що своєю чергою сприяло розвитку креативного мислення.

В. Вернадський зазначав, що дитинство його було доволі щасливим. Отже, можемо робити висновок про те, що він почувався у своїй сім'ї безпечно, у нього формувалась повага до батьків, людей, природи тощо. У сім'ї було закладено базові цінності, які допомогли Володимиру Івановичу надалі проявити свої здібності в декількох напрямах науки.

В. Вернадський любив підкріплювати свої теоретичні знання практично. Він писав, що через природу намагався знайти відповіді на хвилюючі його питання. За допомогою здатності помічати дрібниці він міг систематизувати та застосовувати свої знання, спілкуючись з природою. А як відомо, спостережливість $€$ опорною якістю творчої особистості. За допомогою взаємодії з природою В.І. Вернадський розвивав здібність до розв'язування задач в умовах неповної детермінованості. Тобто намагався пояснити взаємозв'язок того, що у книзі та в житті.

Необхідно відзначити, що особливу роль у розвитку особистості відіграє емоційна атмосфера сім'ї. Приклад батьків $є$ тим першим соціальним досвідом, який засвоюють діти протягом усього життя. Це спілкування специфічне, неповторне, бо воно будується на почутті любові, прихильності батьків до дітей, і навпаки. Батьки впливають при цьому на них усіма сторонами своєї особистості: зовнішністю, поглядами, інтересами, ставленням до праці та до оточуючих. Слід зазначити, що вплив батьківського прикладу посилюється, як правило, загальною атмосферою сім'ї, яка будується на основі групової свідомості і загального стилю поведінки батьків.

Якщо проаналізувати сімейні стосунки у родині Вернадських, то можна відзначити, що батьківським ставленням до синів було прийняття та кооперація. Батьки сприймали Володимира таким, яким він зростав, поважали його індивідуальність, були зацікавлені у розвитку сина, цінили його інтелектуальні й творчі здібності. Також стосунки між батьками, а також батьками та дітьми відзначались гармонійністю. Володимир наслідував творчу особистість батька, його прогресивні погляди, вони мали спільність інтелектуальних інтересів. Необхідно відзначити, що атмосфера в сім'ї Вернадських сприяла залученню дітей до життєвих цінностей батьків. Авторитетне виховання, яке включало підтримку, контроль батьків призвело до того, що сини перейняли цінності своїх батьків [2].
У сім'ях з обдарованими дітьми часто самі батьки мають відношення до творчих або інтелектуальних професій. У системі цінностей такої сім'ї освіта має велике значення, що ми і прослідкували під час аналізу життєдіяльності Володимира Івановича. Приклад його батька в науковій діяльності став важливим чинником наслідування. А серйозне ставлення до освіти синів було поштовхом до прояву їх обдарованості. Отже, спочатку Володимир неусвідомлено наслідував батька, а потім цілком свідомо перейняв його манеру поведінки та ставлення до оточуючих людей. Отже, сім'я Вернадських створила умови для творчого розвитку дітей.

Емоційний клімат сім'ї також досить сильно впливає на розвиток здібностей дитини. Саме позитивний психологічний клімат, доброзичлива атмосфера та атмосфера довіри створюють передумови для розвитку творчої особистості. Слід зазначити, що батькам Володимира Вернадського вдалося створити необхідне розвиваюче середовище, що вплинуло на розвиток його творчих здібностей. Вони сформували атмосферу пізнавальних інтересів: самі багато читали, відвідували спектаклі, не нав'язуючи свого інтересу. Також вони спрямували свої сили на інтелектуальний розвиток дітей, створення умов, що випереджають розвиток дитини, самостійне вирішення складних завдань, надання дитині свободи у виборі діяльності, надавали розумну доброзичливу допомогу, не давали прямих підказок, створили комфортну психологічну атмосферу в сім'ї, заохочували прагнення дітей до творчості.

Також у сім'ї Вернадських приділялась значна увага питанням саморозвитку. Можемо констатувати, що здібність бачити незвичайні речі у звичному, дивуватись та усвідомлювати обмеженість своїх знань, розвиток наукових здібностей В. Вернадський набув у дитинстві. Вся наукова діяльність В.І. Вернадського була спрямована на пошук нових наукових методів та здатність приймати нові теорії, які багатьом його сучасникам здавалися абсурдними. Більшою мірою під впливом батька, двоюрідного дяді та старшого брата у нього сформувались необхідні для науковця якості: вміння спостерігати, аналізувати, сумніватися, не піддаватися сліпо впливу авторитетів (критичне мислення).

Також сім'я Вернадських формувала такі цінності, які згодом перейняв і Володимир Іванович. Серед них були визначені такі як: внутрішня свобода, самоповага, воля, мудрість, розум, урівноваженість в особистих і громадських справах, оптимізм, почуття гумору, терпеливість, зовнішньоетична вихованість, самостійність та критичність мислення, твердість слова, точність, самокритичність, почуття відповідальності, активне слухання, шляхет- 
ність і відповідальність у стосунках з особою іншої статі, самореалізація, розвиток естетичних смаків і творчих естетичних здібностей.

Висновки з проведеного дослідження. Слід відзначити, що світогляд В. Вернадського формувався значною мірою під впливом батька, старшого брата Миколи, а також найближчого оточення наукової еліти. Отже, доброзичлива домашня атмосфера у родині Вернадських, яка була пронизана духовністю, прихильністю один до одного членів сім'ї, взаєморозумінням, бажанням бути корисним для своїх рідних, спільна праця, родинні свята, народні звичаї та обряди надзвичайно глибоко вплинули на становлення та розвиток особистості В.І. Вернадського. Він рано навчився читати і багато часу проводив за книгами, відшукуючи ї у домашній бібліотеці. Велике враження на нього мали географічні книги, описи мандрів і дивовижних явищ природи. Цікавився він також історією, переважно грецькою.
У подальшому планується дослідити професійний шлях В.І. Вернадського, визначити значущі періоди у житті Володимира Івановича та виявити зв'язки між ними і створеними науковими теоріями.

\section{ЛITEPATУРA:}

1. Вернадский В.И. Письма Н.Е. Вернадской (1886-1889).

2. Виноградова В.Є. Ґенеза творчих здібностей видатних науковців (В.І. Вернадського, І.І. Мечникова, К.Д. Ушинського) : монографрія. Київ : Видавництво Ліра-К, 2020. 238 с.

3. Гумилевский Л.И. Вернадский. Москва : «Молодая гвардия», 1967. 256 с.

4. Демчук О. Сімейні цінності як парадигма інституту життєдіяльності. Нова педагогічна думка. 2017. № 1 (89). C. 47-49.

5. Мочалов И.И. Владимир Иванович Вернадский. Москва : Наука, 1982.

6. Ситник К., Бевз Т. Володимир Вернадський: Людина. Громадянин. Учений. Киев : Наукова думка, 2017. 368 c. 